\title{
The role of the medium in sodium saccharin preference in rats
}

\author{
ELLEN F. ROSEN, LINDA C. PETTY*, and WINIFRED L. ANGELO $\dagger$ \\ The College of William and Mary, Williamsburg, Virginia 23185
}

\begin{abstract}
The acceptability curve for sodium saccharin mixed with powdered dry food was determined using 45 female saccharin-experienced rats. Concentrations of $0.00 \%, 0.04 \%, 0.10 \%, 0.16 \%, 0.20 \%, 0.30 \%$, and $1.5 \% \mathrm{w} / \mathrm{w}$ were presented ad lib one per group for 7 consecutive days. The most highly preferred mixture was $.2 \%$ saccharin. A second experiment was performed using 18 naive female rats to determine if moisture increases the palatability of the saccharin mixtures. Adding water did not further enhance the palatability of a $.2 \%$ saccharin mixture any more than it enhanced intake of plain dry food.
\end{abstract}

Sweets generally have positive hedonic value: substances with a sweet taste are ingested in large amounts under "normal" circumstances. Intake of sucrose and glucose solutions of the proper strength by the rat is higher than intake of plain water. This preference, or increased acceptability, may be a response to sucrose and glucose as highly palatable sources of nutriment. Such solutions are "foodstuffs," contributing substance needed for bodily maintenance.

When sodium saccharin is added to water in the proper concentrations, the solution tastes sweet but has no obvious nutritive value. Considering such a solution as "foodstuff" is not accurate, even though such a position is commonly taken. Teitelbaum and Epstein (1963) imply this position when they assert that "normal animals respond to saccharin in water either as a fluid or as a food depending upon whether they are thirsty or hungry [pp.358-359]." Their statement is based on studies of impaired motivation following brain damage and in association with intragastric feeding of a liquid diet. Warren and Warren (1966) try to argue that sodium saccharin is nutritive in the sense that it adds sodium to the diet. This position has been criticized, however, on the grounds that sodium-deficient rats do not increase their intake of a sodium saccharin solution significantly above the level of intake of sodium-sufficient rats (F. Bauer, 1969). Saccharin preference may be solely a fluid-related phenomenon.

Evidence for the positive hedonic value of sodium saccharin has come from many studies, but all reviewed used saccharin solutions. Jacobs and Sharma (1969, p. 1109) have pointed out the importance of the role of the base diet (liquid vs solid) in the case of quinine tolerance. Perhaps the same holds for saccharin. Rats may not prefer any saccharin-adulterated solid-food diets. This experiment attempted to determine what, if

\footnotetext{
* Now at the Department of Psychology. Virginia Commonwealth University. Richmond, Virginia 23220.

Now at the Department of Psychology. Indiana University, Bloomington. Indiana 47401 .
}

any, sodium saccharin strengths were preferred over stock when the mixtures were a saccharin and solid food combination, and to compare a wet-mash base food with a dry base food using the preferred strengths.

\section{EXPERIMENT I}

The first experiment was performed to discover the amount of sodium saccharin necessary to be added to dry stock diet to increase its hedonic value.

\section{Method}

Forty-five female albino rats (Sprague-Dawley-derived, Dublin/SDD, Flow Labs, Dublin, Virginia), 180 days old, were assigned randomly to one of seven groups. All animals were housed individually under 24-h light with ad lib water. Purina Laboratory Chow meal was the stock diet also available ad lib in Wahmann food devices (LC-306-B). All animals, except for the control group $(0 \%$ sodium saccharin, $N=6)$, received prior experience with sodium saccharin and solid-food mixtures. Thus, all animals had been acclimated to the experimental situation prior to testing. Food intake to the nearest 10 th of a gram and body weight to the nearest gram were recorded at the end of each day.

Pilot work had suggested that the most highly preferred sodium saccharin concentration in solid food was between $.03 \%$ and $1.5 \%$, the range of concentrations (weight/weight) tested. This range seemed reasonable since this included the concentration of saccharin usually most highly preferred in water solutions (e.g., Nachman, 1959; Weinstock et al, 1965).

The six experimental groups were assigned randomly one of the following saccharin and meal mixtures: $.04 \%(\mathrm{~N}=6), .10 \%$ $(\mathrm{N}=7), .20 \%(\mathrm{~N}=6), .30 \%(\mathrm{~N}=7)$, and $1.5 \%(\mathrm{~N}=6)$. The mixtures were presented $24 \mathrm{~h} / \mathrm{day}$ for 7 consecutive days. The control group $(\mathrm{N}=6)$ received stock diet for the 7 days $(0, \mathrm{c}$ sodium saccharin). The mixtures were made with a Waring blender to ensure even distribution of the saccharin. The mixtures were stirred both before and after blending to further ensure even distribution of the saccharin.

\section{Results}

A 7 by 7 unweighted means analysis of variance with repeated measures on the last factor, days. was performed on both body weights and food intakes. In 
Table 1

Days of Maximum and Minimum Intakes in Experiment I

\begin{tabular}{|c|c|c|c|c|}
\hline \multirow{2}{*}{$\begin{array}{l}\text { Concen- } \\
\text { tration } \\
\text { of Saccharin } \\
\text { (Percent) } \\
\end{array}$} & \multicolumn{2}{|c|}{ Maximum } & \multicolumn{2}{|c|}{ Minimum } \\
\hline & $\begin{array}{c}\text { Day } \\
\text { Achieved }\end{array}$ & $\begin{array}{l}\text { Intake } \\
\text { (g) }\end{array}$ & $\begin{array}{c}\text { Day } \\
\text { Achieved }\end{array}$ & $\begin{array}{c}\text { Intake } \\
\text { (g) }\end{array}$ \\
\hline .00 & 2 & 14.1 & 4 & 13.1 \\
\hline .04 & 5 & 13.2 & 4 & 11.8 \\
\hline .1 & 1 & 16.6 & 7 & 13.4 \\
\hline .16 & 1 & 15.5 & 7 & 11.7 \\
\hline .2 & 1 & 17.8 & 7 & 13.1 \\
\hline .3 & 1 & 14.3 & 7 & 12.5 \\
\hline 1.5 & 1 & 16.1 & 4 & 13.1 \\
\hline
\end{tabular}

both analyses, the only significant factors were for days $(F=6.56$ for weight and 11.09 for food, $\mathrm{df}=6,228$ ) and for the Saccharin Strength by Days interaction for food intake $(F=1.47, d f=36,228)$. An investigation into this significant interaction was pursued by determining days of maximum and minimum intakes for the different levels of saccharin concentration. This investigation is presented in Table 1. Any strength above $.04 \%$ was preferred maximally on the first day of presentation and least preferred on the last day. The only exception to this rule was for the $1.5 \%$ strength, which was least preferred on Day 4 , as were $.04 \%$ and $0 \%$.

\section{EXPERIMENT II}

The most highly preferred concentration, as shown in Table 1 , was $.2 \%$, and thus this was the strength chosen for the second experiment to see if adding moisture to the diet does, in fact, increase preference. The hypothesis under consideration was that sodium saccharin when in solution is more hedonistically effective.

\section{Method}

Eighteen female rats (Sprague-Dawley derived, Holtzman Co., Madison, Wisconsin), about 150 days old (approximately 230-290 g), were used as Ss. All Ss were housed individually under 24 -h light at about $25^{\circ} \mathrm{C}$. Food and water were ad lib throughout the experiment. Food was presented in foodcups and water in inverted graduated cylinders. A baseline period for food consumption was conducted for 4 days after allowing 2 days of adaptation to foodcups. During adaptation, as well as throughout the baseline period, the stock dry diet (ground Purina Laboratory Chow) was used. The day was divided into an 18-h period (T1) and a 4-h period (T2). T1 was from 21:30 to $17: 30$ and T2 was from $17: 30$ to $21: 30$. Only dry food (stock) was presented during $\mathrm{T} 1$, with all groups getting exactly the same food and water throughout the entire experiment during this period. During baseline measurements, the same diet was also presented during T2 as in T1. On Day 6, the animals were divided into four groups equated for baseline food intake. The groups were (1) $.2 \%$ saccharin (soluble sodium) wet food (WS), (2) $.2 \%$ saccharin dry food (DS), (3) wet food (WF), and (4) dry food (DF). These mixtures were presented only during T2. The wet food was made by combining $40 \mathrm{~g}$ of stock diet with $60 \mathrm{cc}$ of tap water. To make the $.2 \%$ sodium saccharin wet-food mixture, $2 \mathrm{~g}$ of sodium saccharin were added to $600 \mathrm{cc}$ of water and $400 \mathrm{~g}$ of stock diet. The dry-food $2 \%$ sodium saccharin mixture was made by adding $2 \mathrm{~g}$ of sodium saccharin to $1,000 \mathrm{~g}$ of dry food. Measurements of food and water consumption were made for each period. Body weight was measured once a day at the end of T1. After 4 days on the test diets, the animals were all placed on dry stock food for 4 days. Those Ss that had gotten saccharin in their food were given it in their water at $.2 \%$ concentration during $T 2$ on these 4 days to check that these rats did prefer this concentration of saccharin solution over water.

\section{Results}

The data were analyzed using a 2 by 2 by 4 (Saccharin by Wetness by Days) unweighted means analysis of variance with repeated measures on the last factori. The analysis was performed separately on each of the measures (weight, food and water consumption) for each of the 4-day periods. During the baseline period, there was no difference between any of the four groups on any of the measures made. The data for test days are summarized in Table 2. For the days when the test diets were presented, the analysis showed that the groups did not differ significantly on any factor in body weight or water consumption during the 18 -h period (T1). Those animals that were in the two wet-food groups (WS and WF) did drink significantly less water during the 4-h period (T2, test diets available) $(\mathrm{F}=17.26, \mathrm{df}=1,14$, $\mathrm{p}<.01)$. This difference was great enough to show up as a significant difference in total (24-h) water consumption $(\mathrm{F}=6.95, \mathrm{df}=1,14, \mathrm{p}<.05)$. Because the food was diluted with water in the wet groups, the food intake data were converted to caloric intake $(3.61 \mathrm{Cal} / \mathrm{g}$ Purina Chow). During the 18-h (T1) period when all Ss had dry stock diet, there was no difference in caloric intake. The wet groups consumed significantly more calories during the 4-h period (T2, test diets available) (F $=4.96$, df $=1,14 ; \mathrm{p}<.05)$. There was an increase in intake until Day 3 generally for all groups except the dry food in $\mathrm{T} 2$ ( $\mathrm{F}$ for interaction $=7.42, \mathrm{df}=3,42)$. There was a tendency for the saccharin groups to eat more, but it was not significant $(\mathrm{F}=1.85, \mathrm{df}=1,14, \mathrm{p}<.25)$, and there was no interaction of wetness with saccharin $(F<1)$. The solution hypothesis was therefore not confirmed. Further, total (24-h) caloric consumption was not affected by any of the variables, although there was a tendency toward increased consumption by the saccharin animals $(\mathrm{F}=2.42, \mathrm{df}=1,14, \mathrm{p}<.25)$.

During the final 4-day period, when saccharin was dissolved in the drinking water of the two groups that previously had saccharin in their food, there were no significant differences in body weight or in 18-h water consumption. Saccharin was highly preferred over water for the 4-h T2 period $(F=32.53, d f=1,14, p<.01)$. Food consumption showed no significant differences in the second test period (T2). If they had been stressed by the different diets, they would have eaten less of the stock diet. Animals must not consider saccharin to be anything more than a nonnutritive sweetener when presented in fluid, since the increase in fluid intake did 
Table 2

Summary of Average Values of Weight, Water, and Caloric Consumption Throughout Second Phase of Experiment II Presentation of Test Diets

\begin{tabular}{|c|c|c|c|c|c|c|c|c|}
\hline \multirow[b]{2}{*}{ Group } & \multicolumn{2}{|c|}{ Day 1} & \multicolumn{2}{|c|}{ Day 2} & \multicolumn{2}{|c|}{ Day 3} & \multicolumn{2}{|c|}{ Day 4} \\
\hline & $\mathrm{T} 1$ & T2 & T1 & T2 & T1 & T2 & T1 & T2 \\
\hline $\begin{array}{l}\text { Wet Saccharin } \\
\text { Calories } \\
\text { Water (cc) } \\
\text { Weight (g) }\end{array}$ & $\begin{array}{l}29.6 \\
18.0\end{array}$ & $\begin{array}{r}10.4 \\
3.6\end{array}$ & $\begin{array}{l}30.2 \\
17.0\end{array}$ & $\begin{array}{r}14.5 \\
4.0\end{array}$ & $\begin{array}{l}30.3 \\
17.2\end{array}$ & $\begin{array}{r}18.4 \\
3.8\end{array}$ & $\begin{array}{l}29.2 \\
14.4\end{array}$ & $\begin{array}{r}15.2 \\
3.8\end{array}$ \\
\hline $\begin{array}{l}\text { Wet Food } \\
\text { Calories } \\
\text { Water } \\
\text { Weight }\end{array}$ & $\begin{array}{l}30.7 \\
20.0\end{array}$ & $\begin{array}{l}8.8 \\
2.8\end{array}$ & $\begin{array}{l}32.7 \\
19.2\end{array}$ & $\begin{array}{r}11.4 \\
4.0\end{array}$ & $\begin{array}{l}29.5 \\
20.8\end{array}$ & $\begin{array}{r}16.3 \\
4.0\end{array}$ & $\begin{array}{l}27.4 \\
22.0\end{array}$ & $\begin{array}{r}14.4 \\
2.5\end{array}$ \\
\hline $\begin{array}{l}\text { Dry Saccharin } \\
\text { Calories } \\
\text { Water } \\
\text { Weight }\end{array}$ & $\begin{array}{l}34.7 \\
22.2\end{array}$ & $\begin{array}{r}11.8 \\
7.6\end{array}$ & $\begin{array}{l}33.4 \\
22.8\end{array}$ & $\begin{array}{r}11.5 \\
7.6\end{array}$ & $\begin{array}{l}31.3 \\
19.6\end{array}$ & $\begin{array}{r}12.7 \\
6.8\end{array}$ & $\begin{array}{l}32.9 \\
25.0\end{array}$ & $\begin{array}{r}10.7 \\
5.4\end{array}$ \\
\hline $\begin{array}{l}\text { Dry Food } \\
\text { Calories } \\
\text { Water } \\
\text { Weight }\end{array}$ & $\begin{array}{l}31.1 \\
20.2\end{array}$ & $\begin{array}{r}10.2 \\
6.2\end{array}$ & $\begin{array}{l}31.6 \\
19.8\end{array}$ & $\begin{array}{r}11.0 \\
6.5\end{array}$ & $\begin{array}{l}31.9 \\
21.8\end{array}$ & $\begin{array}{r}10.8 \\
5.8\end{array}$ & $\begin{array}{l}31.3 \\
21.0\end{array}$ & $\begin{array}{l}8.8 \\
5.5\end{array}$ \\
\hline
\end{tabular}

not cause a concommitant decrease in food consumption.

\section{DISCUSSION}

The results of these two experiments taken together suggest that rats do not consider a preferred concentration of sodium saccharin in either a food base or a water base to be anything other than a nonnutritive sweetener in either instance, since it does not cause animals to ingest fewer calories than normal, even at the end of 4 days.

Further, evidence has been presented for .2\% saccharin in food as adding positive hedonic value to food in that it produced increased food consumption in the first and second experiments. The second experiment did not produce significance, but this might be due to variations in experimental methods between Experiments I and II. These differences include a change in animal supplier, a change in length of presentation of saccharin, and a change from experienced to naive Ss. The change in length was due to the possibility of wet mash's significantly drying out over a 24-h period. Observations made prior to the experiment indicated that such drying out was negligible over the 4-h period. The change from experienced to naive Ss was also a meaningful change in that there is some evidence from these experiments and many others (e.g., E. Bauer, 1969; Bauer \& Reynolds, 1971) that sodium saccharin preference declines over time.

Finally, a comparison of a wet-based saccharin food mixture and a dry-based saccharin food mixture has been made which has shown that saccharin does not need to be in solution to be preferred. It was also shown that the same concentration in water alone was much more preferred than in food. This finding, plus that of the optimum of $.2 \%$ in food, substantiates that preference curves for saccharin in food and saccharin in water may be different, the optimal for water being .3\% (Weinstock et al, 1965) or $.45 \%$ (Bacon et al, 1962) or $.5 \%$ (Young, 1967).

\section{REFERENCES}

Bacon, W. E., Snyder, H. L., \& Hulse, S. H. Saccharin preference in satiated and deprived rats. Journal of Comparative \& Physiological Psychology, 1962, 55, 112-114.

Bauer, E. R. Deprivation changes initial affective value of sodium saccharin. Psychonomic Science, 1969, 16, 275.

Bauer, E. R., \& Reynolds, E. V. D-amphetamine and palatability of a saccharin solution. Psychonomic Science, 1971, 23, 3-4.

Bauer, F. S. Effects of sodium deficiency on sodium saccharin drinking. Psychonomic Science, 1969, 17, 162-163.

Jacobs, H. L., \& Sharma, K. N. Taste versus calories: Sensory and metabolic signals in the control of food intake. Annals of the New York Academy of Sciences, 1969, 157, 1084-1125.

Nachman, M. The inheritance of saccharin preference. Journal of Comparative \& Physiological Psychology, 1959, 52, 451-457.

Teitelbaum, P., \& Epstein, A. N. The role of taste and smell in the regulation of food and water intake. In Y. Zotterman (Ed.), Olfaction and taste. New York: Macmillan, 1963. Pp. 347-360.

Warren, R. P., \& Warren, R. M. Soluble saccharin preference: A nutritive basic for persistence. Nature, 1966, 210, 310-311.

Weinstock, R., White, R. T., \& Bolles, R. C. Incentive value of saccharin as a function of concentration and deprivation conditions. Psychonomic Science, 1965. 3, 103-104.

Young, P. T. Palatability: The hedonic response to foodstuffs. In C. F. Code (Ed.), Handbook of physiology. Section 6: Alimentary canal. Vol. I. Food and water intake. Baltimore: Williams \& Wilkins, 1967. Pp. 353-366.

(Received for publication October 30, 1972; revision received December 1.1972 .) 